\title{
Han Gothic Town Halls in and around Flanders, Vandevyvere 1350-1550: a Geometrical Analysis
}

Han Vandevyvere undertakes an investigation into some geometrical schemes that can be supposed to underlie the plans and facades of a number of Flemish Gothic town halls, all of them built from the late fourteenth till the early sixteenth century. To govern his study he founded a set of basic ordering rules: a search for simple series of integer numbers, so as to obtain simple ratios between the dimensions; a check to see that what is found to set up a plan is also found in the elevations; the preferential use of geometrical constructions that can easily be constructed with the compass and the carpenter's square; checking the design in the measurement units that were in use at the moment and place of construction; a check for the use of construction based on a circle, its inscribed square and equilateral triangle.

\section{Introduction}

This present article is the result of an investigation into some geometrical schemes that can be supposed to underlie the building-plans of a number of Flemish Gothic town halls. Among the most famous of them, we can mention Brussels, Louvain, Oudenaarde and Bruges, all of them built from the late fourteenth till the early sixteenth century. The starting-point for this investigation was a detailed analysis of the town hall of Louvain [Vandevyvere 2000], and the conclusions resulting from it. All this shows that the building has been set up by using a module based on the local, medieval measurement units. The most important parts of the analysis will be reconsidered in this article. It was so fascinating that, from this analysis, the research has been carrying on to other Gothic town halls in Flanders and the neighbouring regions. The results give evidence of the fact that similar schemes have been applied to these buildings, although with local variations. Consequently, the hypothesis of a set of geometrically designed principles that seem to define a whole range of civic buildings, is put forward. This can be compared to what has already been pointed out for the church-architecture of the middle ages.In order to render an account of every step in the reconstruction of the geometrical system, the article will follow the methodological démarche of the research.

\section{Back-tracking Gothic design techniques: what to look for?}

A major problem in reconstructing scenarios used to design medieval buildings is the lack of hard evidence about them. One of the consequences has been a continuous polemic about whether or not the medieval master builder used some more or less secret schemes (the Bauhüttengeheimnis) [Shelby 1977: 46ff]. One could indeed pretend that back-tracking 
a hidden geometrical composition is just Hineininterpretierung (hind-sight interpretation). This discussion often seems to end up in a confrontation between "believers" and "nonbelievers", each of them furnishing evidence of his or her conclusions. To take into account some justified criticism, from the very beginning the analysis of the town hall of Louvain was approached in a very pragmatic way: if the scheme behind it was not evident and simple, the idea would be rejected.However, there is a double reason for setting up an investigation into the existence of a scheme. First of all, the middle ages were undeniably a time of highly symbolic language. And secondly, the evidence from other research affirmed the point of view that taking a closer look at the Flemish town halls was at least worth doing. For the development of an inquiry, it is necessary to have the disposal of a minimal basic set of rules. There should be little discussion about the existence of these rules, and if so, some rules should be given more credit than others. They should confront the results of a purely graphical/numerical analysis with a set of recognizable ordering principles. However, the symbolic connotation of the design rules or schemes is at this moment not under consideration. Only the "visible" level, the graphical evidence stemming from a plan, is examined. In this way, where Louvain is concerned, different issues were regarded, with a certain "probability rate" for each rule. We want to mention some of them, before reviewing the Louvain analysis itself. The set of basic ordering rules was considered as follows:

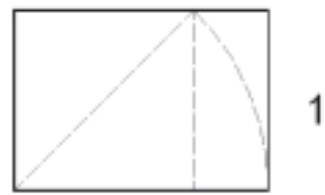

$1.41 \ldots$

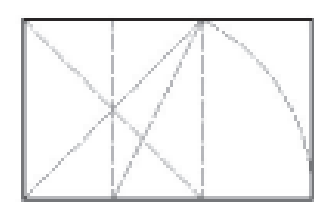

$1.618 \ldots$ or 1$)$
1 (or

$0.618 \ldots)$

Figure 2

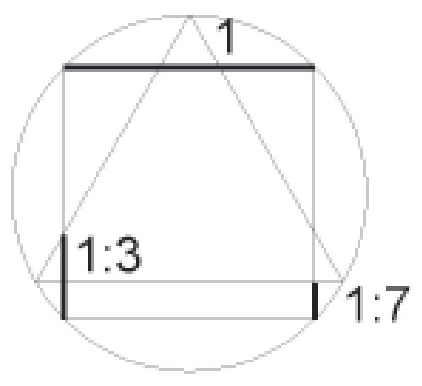

Figure 3

Figure 1

Figures 1-3. Examples of geometric constructions that can be constructed with only a compass and a carpenter's square.

Figure 1 (left) shows the construction based on a square and its turned down diagonal, resulting in a rectangle of which the sides relate to each other in a $1: \sqrt{2}$ ratio $(1: 1.41 \ldots)$. We shall call it the "root-2 rectangle".

Figure 2 (middle) shows the construction based on a square and the corresponding golden section rectangle, defining a ratio of $1:(1+\sqrt{5}) / 2$ or $(1: 1.618 \ldots)$. We shall refer to it as the "golden section rectangle".

Figure 3 (right) is a more complex construction based on a circle, its inscribed square and equilateral triangle. It can be considered as a graphical method of approximatively cutting off one seventh part of the side of a square. We call this the "quatrain scheme".

60 Han VANDEVYVERE - Gothic Town Halls in and around Flanders, 1350-1550: a Geometrical Analysis 
- The preference of the master builder to use simple series of integer numbers, so as to obtain simple ratios between the dimensions;

- What is found to set up a plan should also be found in the elevations. Plan and elevation are linked to each other, as stems from this fifteenth century statement: ...ainer stainwerchs von massen oder von ausczug ... aus dem grunde (zu) nemen: i.e., the measures for the upgoing stone-work are taken from the ground, ${ }^{1}$ a principle that has already been illustrated in multiple occasions;

- The preferential use of geometrical constructions that can easily be constructed with the compass and the carpenter's square, among which we mention:

0 the construction based on a square and its turned down diagonal, resulting in a rectangle of which the sides relate to each other in a $1: \sqrt{2}$ ratio $(1: 1.41 \ldots)$. We shall call it the "root-2 rectangle" (Figure 1);

$\circ$ the construction based on a square and the corresponding golden section rectangle, defining a ratio of $1:(1+\sqrt{5}) / 2$ or $(1: 1.618 \ldots)$. We shall refer to it as the "golden section rectangle" (Figure 2);

- It is in any case advisable to check a design in the measurement units that were in use at the moment and place of construction. As a matter of fact, every Flemish city used a different system of feet and rods; ${ }^{2}$

- Less probable, but to be checked as well, is a more complex construction based on a circle, its inscribed square and equilateral triangle (Figure 3). It can be considered as a graphical method of approximatively cutting off one seventh part of the side of a square. The graphical representation is given in Figure 3, and shows that besides the approximative 1:7 ratio, one can find a similar 1:3 ratio in this scheme. In the analyses that follow, the construction will be referred to as the "quatrain scheme". A medieval quatrain (a type of four-line verse) is said to state this method. The German version of this quatrain is cited by Mathila Ghyka in his work on the Golden Section [Ghyka 1969: 72], whereas the French version of it has been mentioned by Johan Ballegeer in a study on the town hall of Bruges [Ballageer 1987: 20]. It goes as follows:

Un point dans un cercle

Et qui se place dans le carré et le triangle;

Connais-tu le point? Tout est pour le mieux;

Ne le connais-tu pas? Tout est en vain. ${ }^{3}$

J. Ballegeer has applied the corresponding scheme to the latter building. This analysis is discussed below.

As a general principle, we assume that the more simple and straightforward a scheme is, the more probable its original intention looks. A major issue, then, is the precision that should be requested for such a scheme.

Close observation of the town halls in the study seems to indicate that the medieval builder had another concept of precision than we have. For example, he did not feel obstructed by particular conditions of the program or building site that would prevent him from realizing a scheme to the centimetre. A striking example of this flexibility and freedom is the sophisticated use of 'near-symmetry' in a design. Symmetry as we understand it nowadays is a concept derived from rationalistic thinking - we may call 
it mathematical or 'dead' symmetry. The middle agers however made much use of 'natural' symmetry, such as we find, for example, in the composition of the human face. In this case, there is a balance between two opposite aspects: as a consequence, something looks symmetrical, but it is in fact assymetrical. A lot of evidence for this way of working was found in the Louvain town hall [Vandevyvere 2000: 173-177]. It is significant that in the eighteenth century, in Louvain as well as in Bruges, the façade of the town hall was altered to make it look more strictly symmetrical - following the new fashions, a proof of the "distance of spirits' that was emerging with the "Enlightenment".

Arguments similar to those for symmetry apply as well to measuring. The often noticed, unaccounted deviation from a strict scheme, apparently without any valid reason, stands in contrast with the simultanuous rigorousness of that scheme. It would appear that the medieval builder appreciated the contradiction as a mode of expression, a language corresponding with his world-view. This puts us in a difficult situation, apparently taking away the ground we are standing on to prove the very existence of the scheme. It will turn out that only by considering every case individually, we can evaluate the grounds.

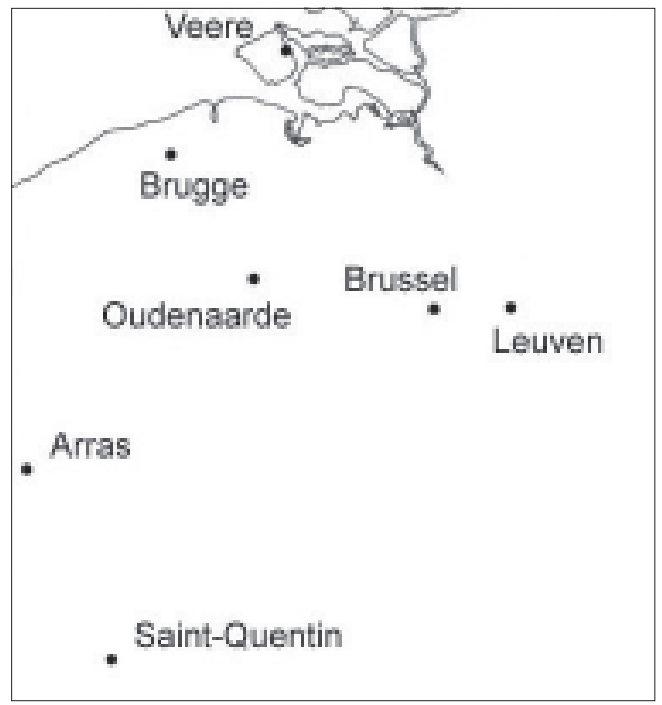

Figure 4

Figure 4. Map indicating the locations of Town Halls in the present study: Brussels (Brussel); Bruges (Brugge); Oudenaarde; Veere; Louvain (Leuven); Arras; Saint-Quentin.

Figure 5. The Louvain town hall, or more precisely the Voirste Huys (front house) of it, was built between 1448 and 1469 .

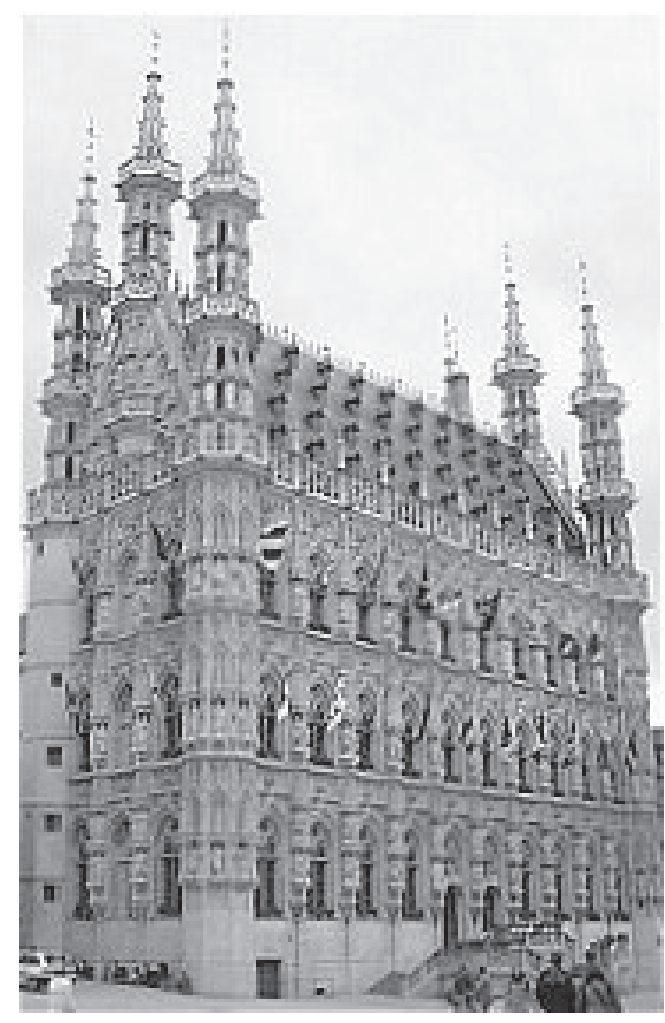

Figure 5

62 Han Vandevyvere - Gotbic Town Halls in and around Flanders, 1350-1550: a Geometrical Analysis 
In other words, the argument of precision is not handled in a theoretical way, but in a practical and case by case approach. The master builder had a unity in thinking and handling - let us call his attitude a particularistic approach within a general frame and by consequence we should try to re-enter this spirit rather than to look through our own conceptual glasses, since these are defined by our own time and culture. Another illustration of the need for this switch in attitude could be the quatrain scheme: it gives indeed about one seventh of the side of the square, but with an error of about $2.5 \%$. It is not the mathematical construction of 1:7. Or, to use still another example: if nature, and so reality, always approaches the golden section but never exactly achieves it, why should one try to represent it exactly in a design? ${ }^{4}$

A totally different aspect of the precision issue is the availability and reliability of the surveys used. These are mostly plans made in the twentieth century for restoration purposes. ${ }^{5}$ For Louvain, the existing plans of the building were controlled by re-measuring important points of the building on the site, in a combined digital and traditional way, that is, using a combination of "computerized" tools such as a "full station" and "traditional" tools, without electronics or integrated data processing. From these measurements, the plans were re-calibrated so as to obtain a precision from 5 to 10 centimeters. The reference is the size of the building, \pm 30 meters wide (by 10 meters deep and 50 meters high), so as an average we speak about a $0.25 \%$ relative error on measurements: $7.5 \mathrm{~cm} / 3000 \mathrm{~cm}=0.0025 \%$. The deviation of the original plans mostly proved to be minimal and of no influence to the conclusions of the analysis. For the other buildings analysed here, only in situ re-measuring will give absolute certainty about the precision of the survey drawings. It should be said, however, that the schemes and principles put forward in this study absorb without problems small deviations such as those resulting from 'average accurate' building surveys.

Altogether, seven buildings will be examined, more or less in detail. A major group of four are located in the actual Flanders (the former Flanders and Brabant): Louvain, Oudenaarde, Brussels and Bruges. A minor group of three is located just over the borders: Arras and Saint-Quentin in North France, and Veere in the Southern Netherlands (Figure 4). All of the latter are situated on a location that was once part of Flanders, or under a strong influence of it.

\section{Louvain, starting point for the analysis}

As mentioned before, the town hall of Louvain, near Brussels, was investigated first. The material resulting from this analysis was important for carrying on the research to other buildings.

The Louvain town hall, or more precisely the Voirste Huys (front house) of it, was built between 1448 and 1469. Louvain intended to build a prestigious project (Figure 5), especially intended to surpass in splendor the recently finished town hall of Brussels. The design as it stands now was provided by Mattheus De Layens. To trace series of numbers in the dimensioning of the building, we should think in Louvain feet and rods. One foot in Louvain stood for $0.2855 \mathrm{~m}$, and 20 feet composed one rod $(5.71 \mathrm{~m})$. We consider now the axial dimensions of the building: 

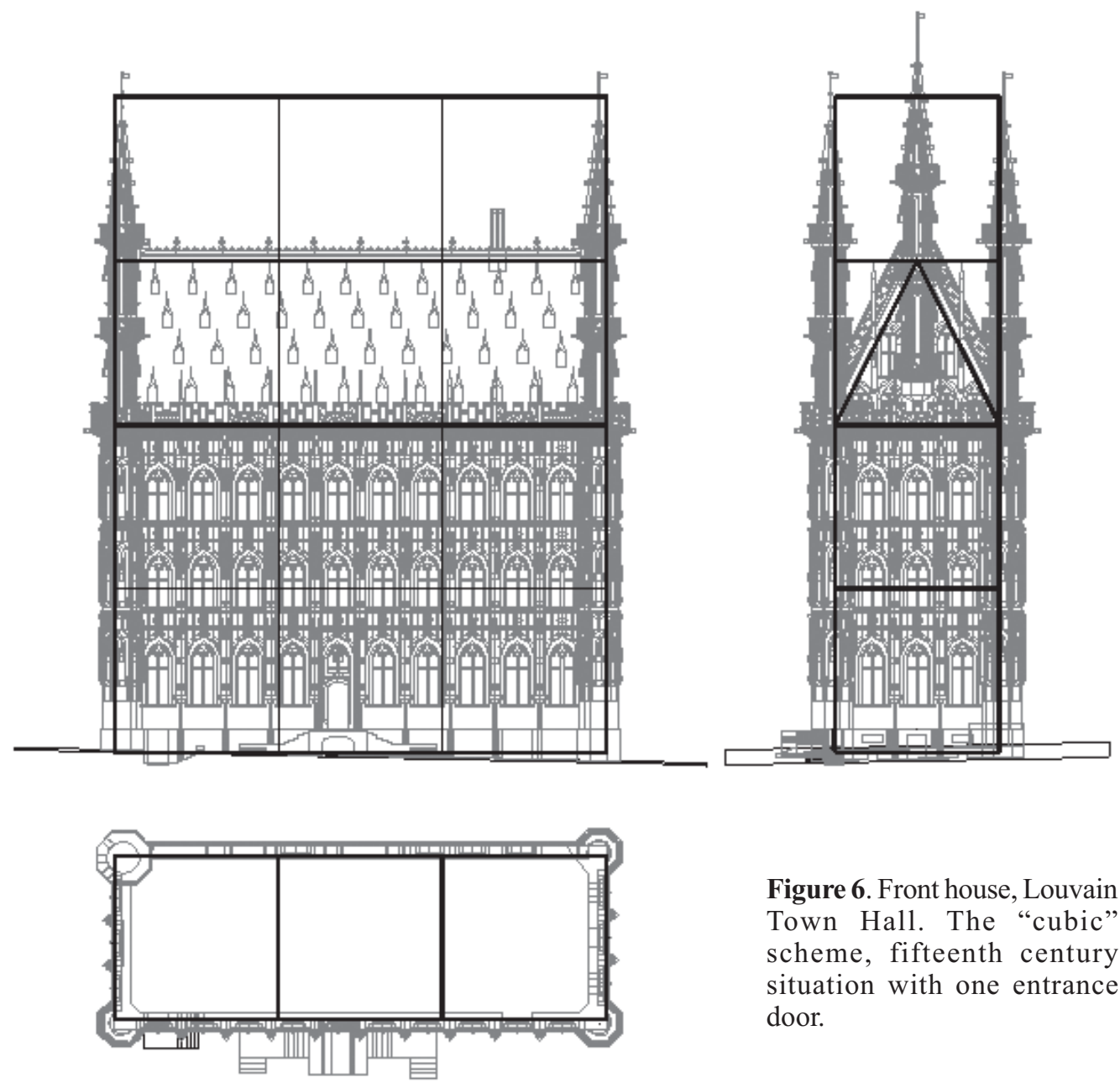

Figure 6. Front house, Louvain Town Hall. The "cubic" scheme, fifteenth century situation with one entrance door.

Length of the building, between the centre lines of the towers: $33.42 \mathrm{~m}$ or 5.85 rods Depth of the building, between the centre lines of the towers: $11.91 \mathrm{~m}$ or 2.09 rods Height from the average ground level up to the cornice of the roof: $22.86 \mathrm{~m}$ or 4.00 rods Height up to the ridge of the roof: $34.98 \mathrm{~m}$ or 6.13 rods Height up to the top of the corner spires (enveloping cone): $\quad 46.12 \mathrm{~m}$ or 8.08 rods Height up to the top of the mid spires:

$50.18 \mathrm{~m}$ or 8.79 rods

All measures are a multiple of $\pm 5,75 \mathrm{~m}$ or \pm one rod. If we consider this $\pm 5.75 \mathrm{~m}$ as a module $\mathrm{M}$, then we can find the average value for $\mathrm{M}$ by summing up all the given dimensions of the building and dividing the result among the corresponding summed number of modules $M$ that these dimensions are supposed to represent:

Sum of the dimensions:

$199.47 \mathrm{~m}$ or 34.93 rods

64 Han VAndevyvere - Gothic Town Halls in and around Flanders, 1350-1550: a Geometrical Analysis 
Figure 7. a) Graphical analysis of the Louvain town hall, or more precisely the Voirste Huys (front house) of it; b) Front facade, Bruges Town Hall.

Figure 8. Graphical analysis showing the quatrain sheme on the Louvain town hall, or more precisely the Voirste Huys (front house) of it.
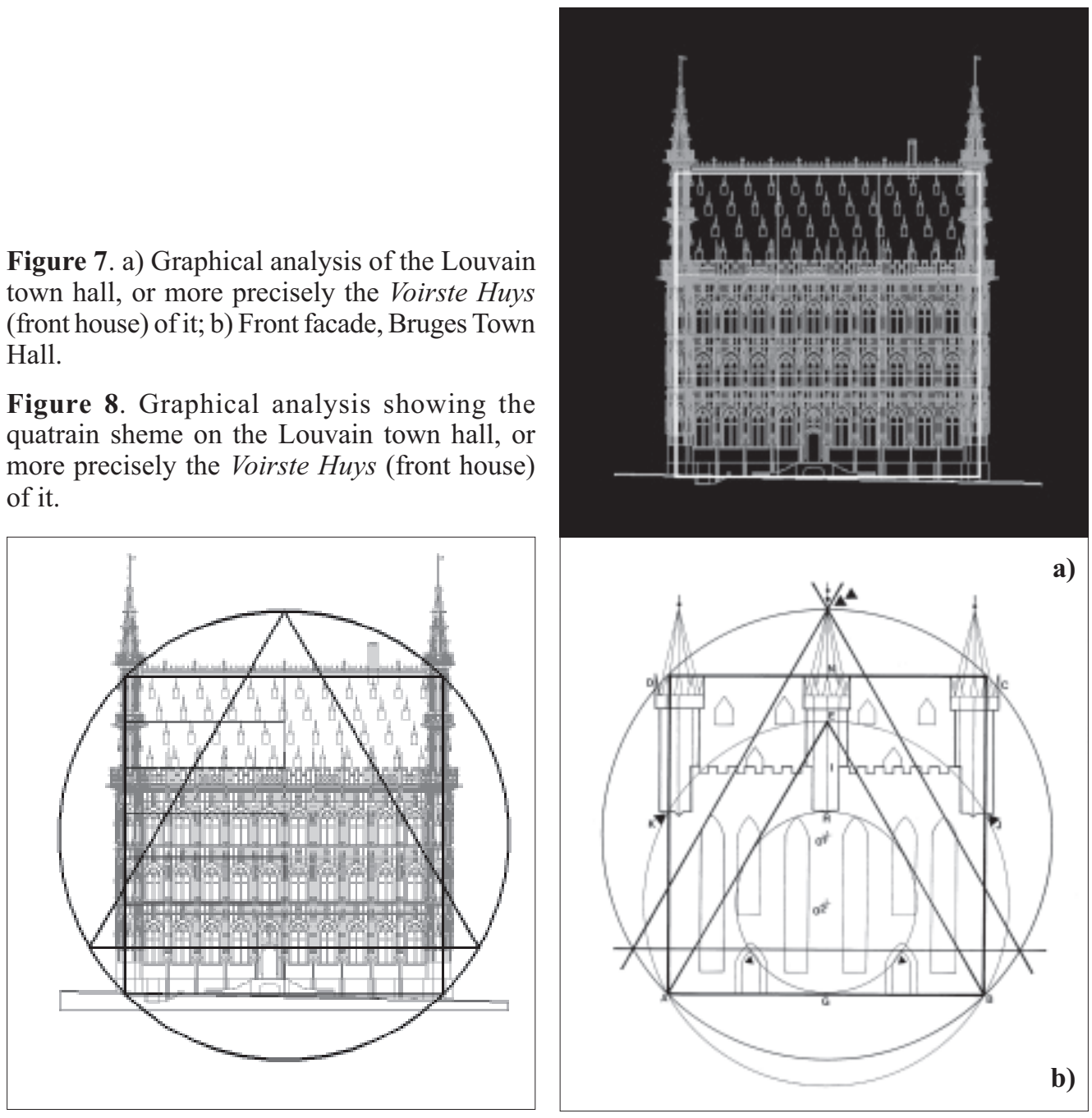

Figure 8

Figure 7

$\mathrm{M}=199.47 \mathrm{~m} / 35=5.699 \mathrm{~m}=0.998$ Louvain rod

We can conclude that the Louvain rod was the basic module to set out the plans and elevations for the building. The error of the calculated module (5.699) in comparison to the assumed module (one rod or $5.71 \mathrm{~m}$ ) is only $0.2 \%$. The deviation of any individual dimension from the assumed modular dimension is never more than $4.3 \%$, and the average deviation for all the dimensions is $2 \%$. All of this is calculated in the supposition that we were always counting from the right reference line.

It is far more interesting to look for what this gives in a graphical way (Figure 6). The building can thus be considered as inscribed in a juxtaposition of cubes, all of them 
having a side of two Louvain rods $(=2 \mathrm{M})$. Only for the top of the mid turrets, the cubic mesh should be subdivided into cubes of a side half so long $(=\mathrm{M})$. The plan is 1 (major) cube deep and 3 cubes wide. Up to the roof cornice, we have a height of 2 cubes, up to the roof ridge, 3 cubes, and up to the top of the corner turrets, 4 cubes, together all of them are defining the basic volumetry by a simple series of the numbers 1-2-3-4. For the four corner turrets, the second node of the metal flag coincides with the top of the enveloping cone of the spire and indicates the cubic gridpoint; for the two mid-turrets the top flag itself indicates the modular gridpoint. The cubic grid only defines the dimensions of the shrine-like volume of the building, and clearly not the division of the façades. No corresponding positioning of interior floors and walls (omitted in the ground plan scheme) was noticed either.

Whether the grid lines should be considered as centre lines or exterior edges, is hard to define. It looks rather as if the architect made a modular "sketch design" volume, and later detailed the building in a more free way. Within the $2 \mathrm{M}$ cubic grid, the roof profile is obtained by constructing a triangle from the base of one of the major squares to the midpoint of its top side. This explains why we have indeed a measured roof slope of 63.4 degrees, this angle being exactly the arctangent of a 2:1 ratio.

Another conclusion which can be derived from the graphical representation is that the projection of the front façade is, with the exception of the turrets, inscribed in a square (Figure 7a). At this point it becomes interesting to compare the front façade with a scheme provided by J. Ballegeer for the Bruges town hall (this scheme will be further elaborated and commented on below). A square appears to define the basic contour of the front façade in this case too. Carrying on the analogy, we can verify the results of the superposition of the "quatrain scheme" on both façades. We first look at some aspects of the Bruges front façade. Here, the contouring square measures 7 Bruges rods. We notice that the front doors are 1 Bruges rod high, and that the top of the balustrade battlements ${ }^{6}$ is at 5 rods from the ground level (i.e. 5/7 of the square side).

If we draw the same scheme on top of the Louvain front façade (Figure 8) and indicate the seventh parts of the square side, we notice that the top of the front door equally corresponds with level 1/7 of the square side, and the top of the balustrade with 5/7. The 1/7-line for the door seems to explain why it has a strange cut-off from the window rhythm, letting two minuscule openings between the top of the door arch and the horizontal cross arms corresponding with the overall window division line at that level. Moreover, the lines $2 / 7$ and 3/7 coincide with horizontal ridges in the stonework. However, the whole thing is put into question if we look at the line 4/7, which has no echo in the façade. Therefore we accept the scheme for what it is and make no further conclusions.

Summarizing the analysis for Louvain, ${ }^{7}$ we can say that:

- The building volume is based on a cubic grid, modulated following the local measurement system. The width of the main cubes is 2 Louvain rods, and the width of the secondary cubes is $1 \mathrm{rod}$;

- The projection of the front façade shows a contouring square for the composition, with dimensions of 6 by 6 rods;

66 Han VANDEVyvere - Gothic Town Halls in and around Flanders, 1350-1550: a Geometrical Analysis 
- Superimposing the quatrain scheme on the front façade, we notice that the division in seventh parts gives the level lines for some major composition elements such as the top of the front door (1/7) and the top of the roof balustrade (5/7). Evidence for the intentionality of the quatrain scheme is, however, weak.

\section{Oudenaarde, early Renaissance perfection}

The second building to be analysed is the town hall of Oudenaarde (Figure 9a). The construction was started in 1526 by Hendrik Van Pede, and in 1530 the building was about finished. Looking at the ground plan, one immediately sees that a square defines its set up (Figure 9b). However, the elevations do not show a likely evident scheme. We start again with a numerical analysis of the major dimensions of the building. Therefore we should measure it in Oudenaarde feet ( 1 foot $=0.2851$ metre $)$ and rods ( $1 \mathrm{rod}=21$ feet [i.e., $3 \times 7$ feet] $=5.9871$ metre) [Vandewalle 1984: footnote 4]. The axial / external measures of the building:

Front façade:

length on the turret axes: $\quad 24.0 \mathrm{~m}=4.01$ rods

external measure: $\quad 24.2 \mathrm{~m}=4.04$ rods

West façade:

length on the axes: $\quad 23.4 \mathrm{~m}=3.91$ rods

external measure: $\quad 24.2 \mathrm{~m}=4.04$ rods

Height level 0 to ridge of the main roof: $\quad 28.2 \mathrm{~m}=4.71$ rods

Height level +1 to ridge of the main roof: $\quad 23.1 \mathrm{~m}=3.86$ rods

Considering different compositional elements, it becomes clear that the building should be thought of as constructed on a socle. This socle is formed by the ground level. The main, representative floor with its big hall is situated at level 1 , and this fact is visually accentuated in the exterior by the gallery that jumps out from the front façade. As such, the building volume above the socle appears to be based on a cube of $4 \times 4 \times 4$ Oudenaarde rods (given a cube with 23.45 metre side, the deviation from 4 rods is $2 \%$ ). Again, the result is best appreciated from a graphical representation (Figure 10ab and Figure 10c). Subdividing the overall cube in smaller cubes with a side of either 1 or 2 rods, we only arrive at the conclusion that the cornices are halfway the height of the 4 rod cube. The lateral gable is inscribed in a 2-rod square whereby its top is situated at the midpoint of the upper side, a scheme we have found in Louvain too. However this square is shifted a little bit to the left in order to accommodate the front gallery. Whether the general diagonal coinciding with a side of the gable triangle defines also the position of the tower top, remains a speculation. Again, the cubic system does not at all define the divisions of the façades.

We now consider another numerical system emerging from the 7 bays division. The average width of a bay of the front façade is, expressed as a fraction of the total width, 4/7 rods or $(4 \times 3 \times 7) / 7=12$ Oudenaarde feet. In reality, the centre bay with the tower and the two outer bays are a bit wider, and the others are a bit narrower. The main hall of the ground floor, on the other hand, is composed of a 3/7 square with respect to the basic 4-rod 

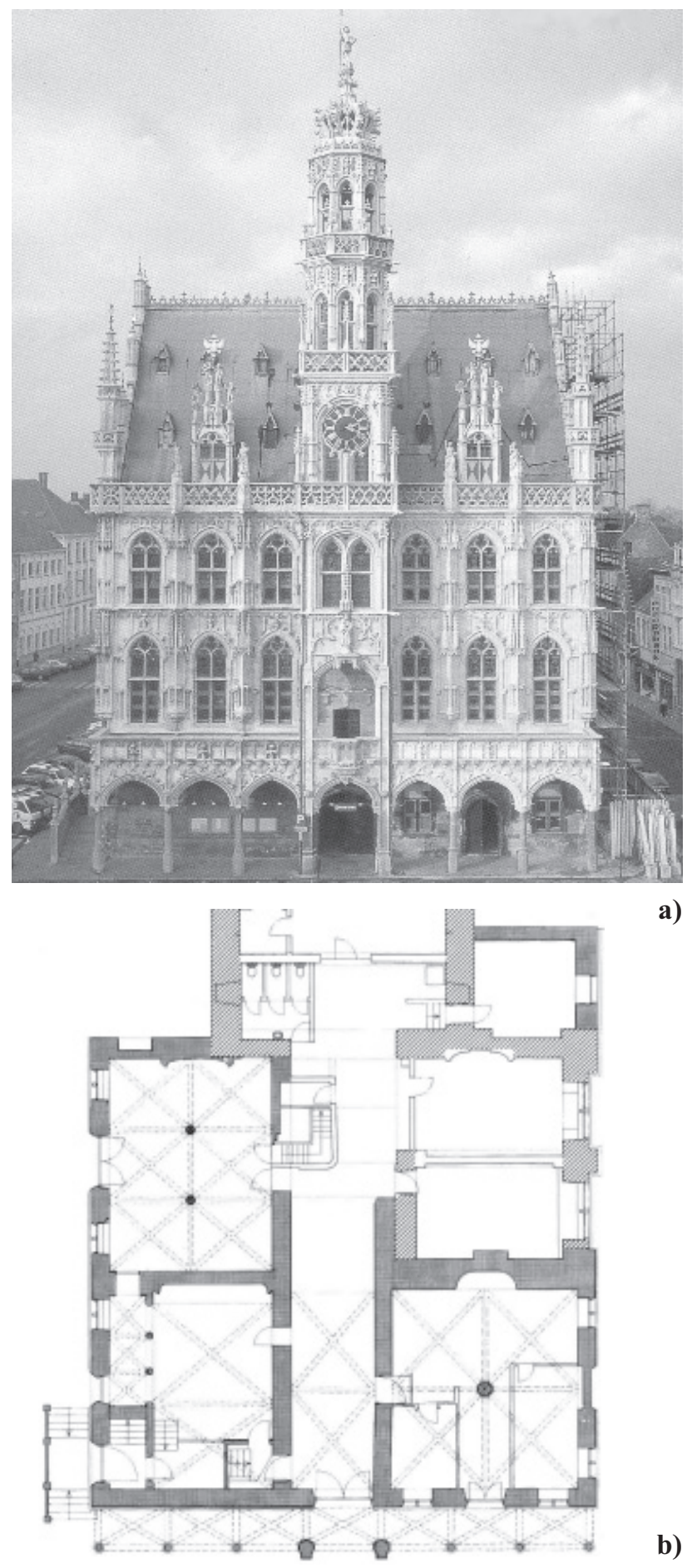

a)

Figure 9. Town Hall at Oudenaarde.

a) front façade;

b) b) ground plan.

68 Han VANDEVYVERE - Gothic Town Halls in and around Flanders, 1350-1550: a Geometrical Analysis 

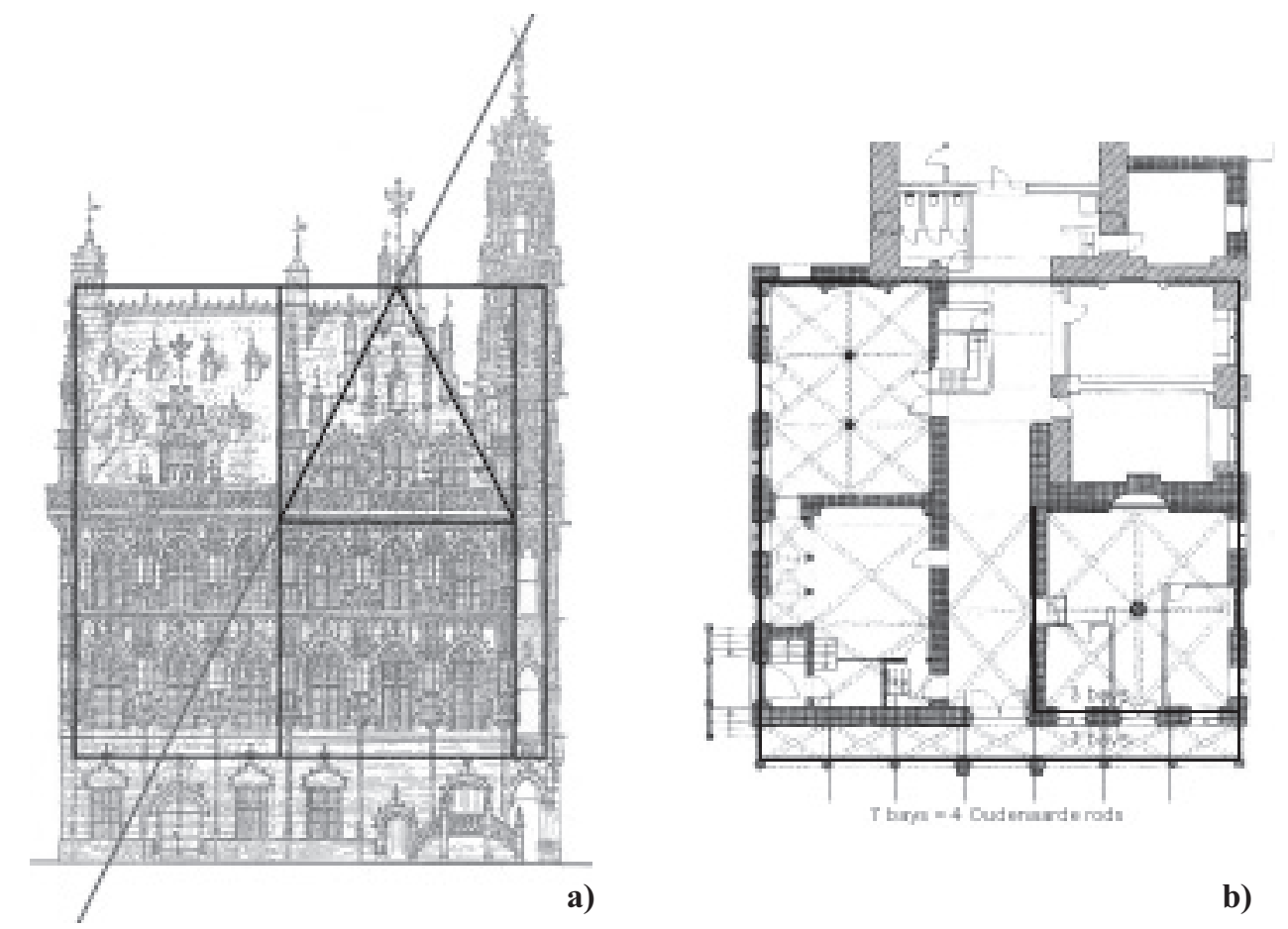

a)

b)

Figure 10. Town Hall at Oudenaarde.

a) analysis of west façade;

b) analysis of ground level plan;

c) Graphical analysis showing the quatrain sheme on the the front facade.

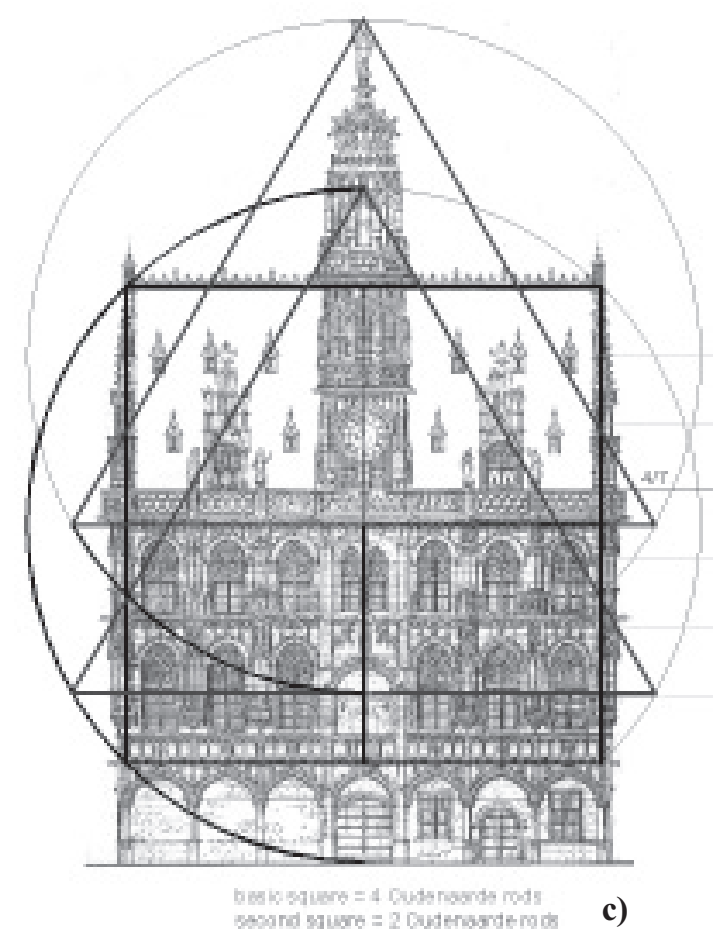

Nexus Network Journal - vol. 3, NO 2, 2001 
square, or $3 \times 12$ feet. The front gallery has a depth of 7 feet. Further along the 4/7 position of the balustrade top in elevation will be discussed (i.e., $4 \times 12$ feet from the base of the main square). It is interesting to notice a preferential occurence of the numbers $1-3-4-7-12$, where $7=3+4$ and $12=3 \times 4$ so that the basic trio is $1-3-4$. The rod itself, by being $3 \times 7$ feet, causes part of the "number system" and is as much of a symbolic character.The next step in the analysis consists in superimposing the quatrain scheme on the front façade. We can now establish the following observations:

- The height of the socle is defined by the quadrant point of the circle circumscribing the $4 \times 4$ rod square;

- Dividing the vertical side of this square into sevenths, we see that the top of the balustrade is at the 4/7 level line;

- The sides of the corresponding equilateral triangle coincide with the outer roof planes of the two main lucarnes, whereas its top coincides with a central pointed arch of the belfry tower.

By shifting this scheme half a radius $\mathrm{R}$ of the circle upwards, i.e., putting the base of the new equilateral triangle at the midpoint level of the 4 rod square (or situating the new quadrant point of the circle on the base of the equilateral triangle), we notice further that:

- The top of the $\mathrm{R} / 2$ shifted triangle indicates the top of the tower.

Finally we should notice that the quatrain scheme is another reference to the 1-3-4 series, the circle having 1, the triangle 3 , and the square 4 sides. Comparing Oudenaarde to Louvain, we find a lot of common points. However, where Louvain seems to have a more arithmetic character (numerical juxtaposition), Oudenaarde relies more heavily on the quatrain scheme and is essentially geometric. Oudenaarde shows a Renaissance influence in its careful and precise elaboration. This is in contrast with numerous earlier buildings where one did not worry about a wall or more standing "out of line" (see further with Brussels, Bruges and Veere). Summarizing the schemes for Oudenaarde, we can say that:

- The building volume is elaborated following the local measurement system, and is basically defined by a $4 \times 4 \times 4$ rod cube put on a socle.

- The front façade composition originates from a contouring square which represents the front face of this 4-rod cube.

- Drawing the quatrain scheme from this square establishes some key points of the composition, and the same is in force to the division of the square into sevenths.

- Shifting this scheme $\mathrm{R} / 2$ up gives the height of the belfry tower.

\section{Brussels, a bit of chaos}

Analysing the town hall of Brussels, one of the most famous examples, is anything but comfortable (Figure 11). It has a scattered building history and there exist two different local measurement systems [Vandewalle 1984: footnote 4], one in which a rod is composed of $161 / 3$ feet and another one in which a rod is $171 / 3$ feet. In contrast with the systems of Oudenaarde ( $1 \mathrm{rod}=21=7 \times 3$ feet $)$ or Bruges $(1 \mathrm{rod}=14=7 \times 2$ feet $)$, working with these numbers is cumbersome. The analysis that follows is only fully elaborated for the 


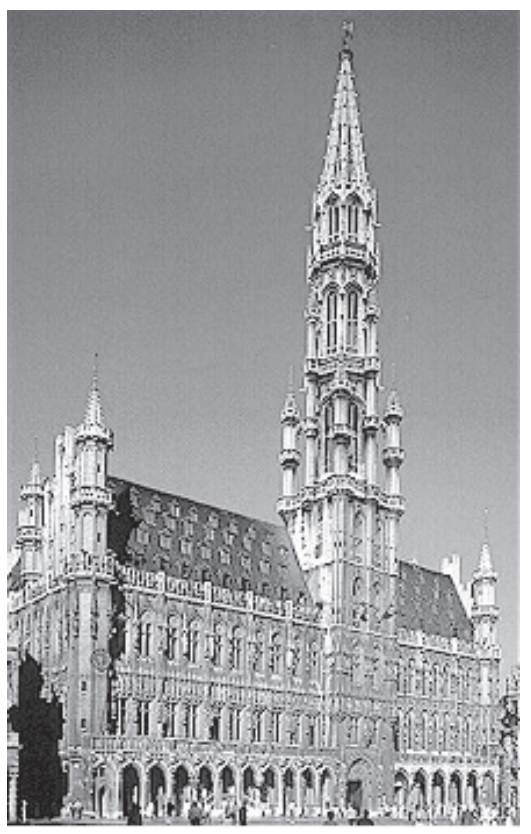

Figure 11

Figure 11. The Town Hall of Brussels.

Figure 12. Hypothetical graphical analysis of the Town Hall of Brussels.

Figure 13. Town Hall at Brussels. a) analysis of South-East facade (left wing); b) final analysis of ground level plan; c) Front facade (left wing).

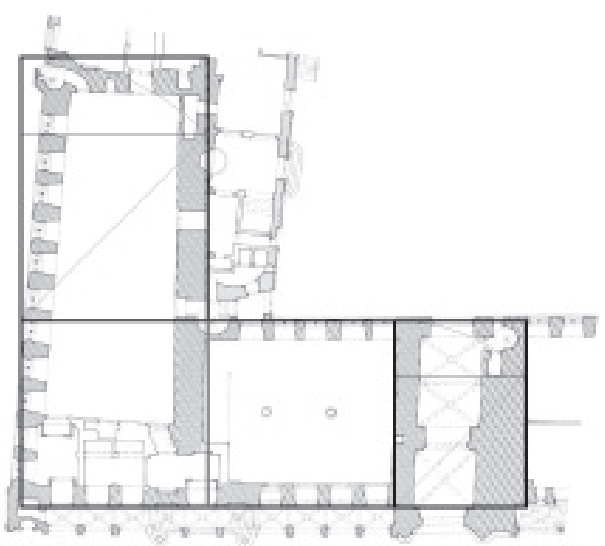

Figure 12
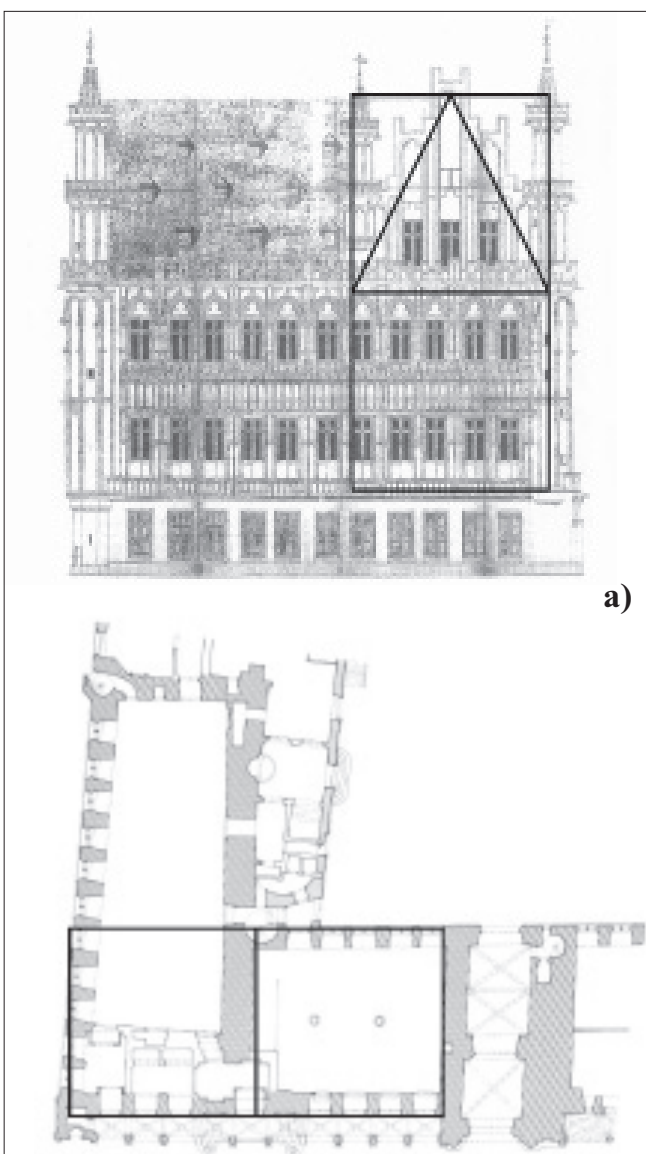

a)

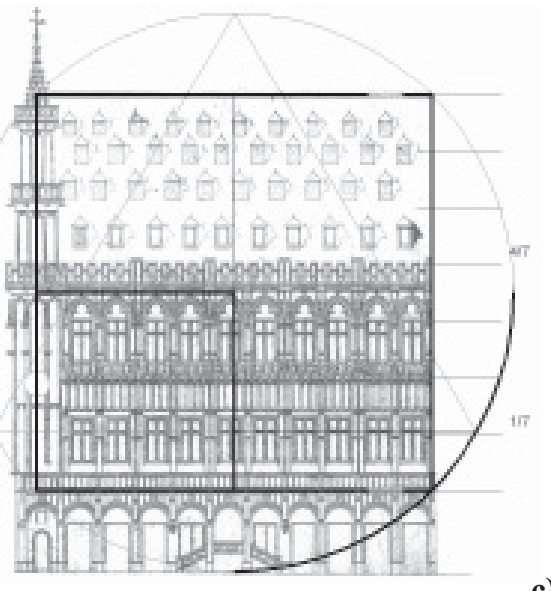

c) 
front part of the left wing. This wing was first constructed from 1402-1420, together with the initial belfry tower. Jakob van Tienen was most probably the architect [Maesschalck and Viaene 1960]. Later, from 1444-1455 the tower was made higher by Jan van Ruysbroek, and three houses to the right were incorporated in the complex, in a manneristic style. However, close observation of the façade of this newer wing shows fundamental differences with the older one. Moreover, as a whole, the town hall composition is severely asymmetric. This asymmetry is rather historical and accidental, and not of the subtle kind such as we find in Louvain. For neither the back part of the left wing (the Gothic side wing) nor for the right wing has a sound geometrical system been found. Data was lacking to complete an adequate analysis of the tower. For the right wing, different master builders and construction periods may be responsible for the loss of a unitarian geometrical scheme. For the left side wing and the tower, a hypothesis can be brought forward, but with some reservation.

The local measurement units are as follows: 1 foot $=0.27575$ metre; 1 rod $=161 / 3$ feet $=4.5039 \mathrm{~m}$ (the small rod) or $171 / 3$ feet $=4.7797 \mathrm{~m}$ (the big rod).

We now proceed with the numerical analysis of some major dimensions. The axial / external measures of the first building phase (1402 - 1420) (with exception of the tower):

Front façade, length on the axes: $\quad 27.40 \mathrm{~m}=6.08$ small rods $=5.73$ big rods East façade (front house), length on axes: $13.25 \mathrm{~m}=2.94$ small rods $=2.77$ big rods East façade (remainder side house): $\quad 19.00 \mathrm{~m}=4.22$ small rods $=3.98$ big rods Height level 0 up to the main roof ridge: $33.50 \mathrm{~m}=7.44$ small rods $=7.01$ big rods Height level 1 up to the ridge of the roof: $27.50 \mathrm{~m}=6.11$ small rods $=5.75$ big rods The axial / external measures of the second building phase (1444 - 1455):

Front façade, length on the axes: $\quad 20.90 \mathrm{~m}=4.62$ small rods $=4.35$ big rods.

As in Oudenaarde, it becomes clear that level 1 is to be taken as a reference plane. The initial front house of 1402-1420 is based on a volume of $3 \times 6 \times(3+3)$ small Brussels rods, put on a socle. Also here, the socle is clearly marked by the gallery of the front façade. The contouring square of this façade is consequently 6 small rods large or 98 Brussels feet. The profile of the attic is found from a triangle within the top lateral square of 3 rods, in a similar way as for Louvain and Oudenaarde.

The depth of the side wing seems, at first sight, rather to obey a $\sqrt{2}$ proportion: 3 rods $x$ $\sqrt{ } 2=4.24$ rods. Or did the master builder play a joke by building the side wing 4 large rods deep? (In the same way, we can wonder if the 7 big rods total height of the building is a coincidence.) Since this wing is not completely perpendicular to the front side, it is better to judge things from a graphical point of view. A hypothesis is put forward in Figure 12, but it remains largely uncertain. It looks as if the tower section can be incorporated in the $\sqrt{2}$ system, and it belongs indeed to the same building phase. But a number of strange constructive arrangements in the tower should be further investigated before any conclusion is made. The second building phase seems to lack any of the logic of the first. A less clear concept stems also from the façade composition: cut off windows, leaping bays. We didn't take the analysis any further. 
The front façade of the left wing is most promising for further investigation, since it presents the original design, and has the contouring 6 rod square. Again, the cubic grid does not account for façade divisions such as window framing. However, superimposing the quatrain scheme on this façade, we find some striking coincidences with the scheme of Oudenaarde:

- The height of the socle is defined by the quadrant point of the circle circumscribing the $6 \times 6$ rod square;

- Dividing the vertical side of this square into sevenths, we see that the top of the balustrade is at the 4/7 level line.

We may conclude that there was a basic scheme for setting out the plans for the first building campaign, very much as what is found for other town halls. How the schemes should be interpreted for the side wing and the tower section remains rather unclear. Further analysis is needed. For the additions of the second building campaign, the question is if any scheme was followed at all.

We may say that Brussels is not only very renowned, but enigmatic as well and even

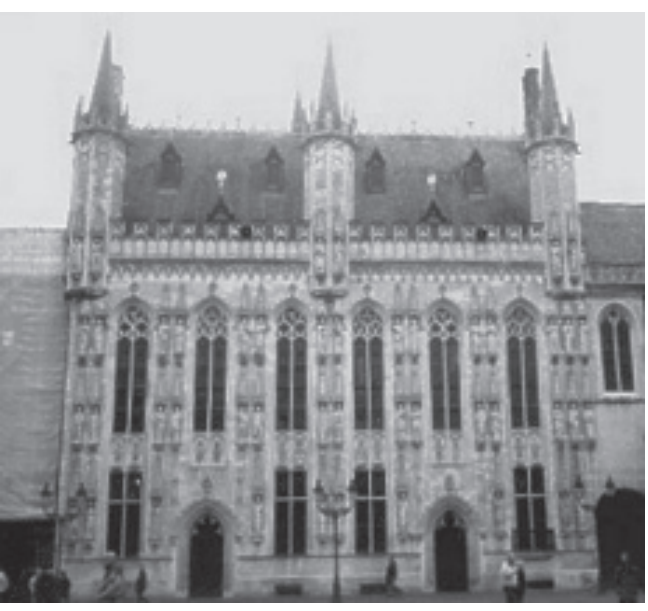

Figure 14. The town hall of Bruges, 1376 to 1420 chaotic. And so it is not surprising that several historians have troubled their heads about its fuzzy logics by trying, for example, to explain the eccentric position of the tower gate. Where ratio fails, legend finds a solution: it says that the architect saw his "mistakes" only after completion of the building (!), and committed suicide. Summarizing the schemes for the first phase of Brussels (Figure 13ab and Figure 13c), we can say that:

- The front part of the building volume is based on a cubic grid, where one cube has a rib of 3 small Brussels rods;

- The front façade composition originates from a contouring square of 6 small rods wide;

- Drawing the quatrain scheme and the seventh-part division from this square, establishes some key points of the composition.

\section{Bruges, the founding father}

The town hall of Bruges was built from 1376 to 1420 and is one of the initial examples at the base of a whole tradition (Figure 14). In its construction intervened three people who might be the architect: J. van Rijsel, M. Saghen and J. Roegiers. The analysis for Bruges was performed mostly graphically, with an in situ control measurement for the length of the front façade. The local measurement units are as follows : 1 foot $=0.2743$ metre; $1 \operatorname{rod}=14$ feet $(2 \times 7$ feet $)=3.8402$ metre [Vandewalle 1984: footnote 4 ]. 
We have hypotheses put forward by J. Ballegeer [Ballegeer 1987] concerning two elements: 1) The basic volume under the roof has 7 x 5 x 3 Bruges rod dimensions, whereas the overall height of the composition is 7 rods; 2) The quatrain scheme can be applied to the front façade, as shown in Figure $7 \mathrm{~b}$. These observations can be analysed, commented and eventually further elaborated.

First the precision of the volumetric modulation is examined. The in situ measurement of the front façade gives us a length of $26.38 \mathrm{~m}$, equal to 6.87 Bruges rods. This means a deviation from the theoretical 7 rods of $1.9 \%$, which is highly acceptable (Louvain had typical deviations of $2 \%$ on average). Secondly, Ballegeer does not account for the roof volume in Figure $7 \mathrm{~b}$; he only considers the turrets for analysing the upper part of the façade composition. However, it has become clear from the other examples that the roof also obeys the overall geometrical concept. So we will reconsider the building volumes and the front elevation, based on a set of survey plans made by L. Devliegher and J. and L. Vierin.

The quatrain scheme provided by Ballegeer goes further in its elaboration than what we have put forward up to now for the other town halls. He has confirmed that it is a compagnonesque construction, thus pointing at an essential source of information. The "Compagnons" indeed originate from the medieval building lodge tradition. ${ }^{8}$

In the present approach, the quatrain scheme was only used in its most basic form when analysing the other town halls. As said before, this is for reasons of evidential value. The more complex the proposed composition rule, the more evidence should be carried for it. In other words, if we should want to do further investigation on the application of the quatrain principle, we should have the disposal of more precise and parallel information in addition to what is gained from a first, purely dimensional, analysis. Because we don't have this detailed information at this moment, we look again at what is the result of the "basic" analysis, keeping in mind the findings of the other designs. It should also be noticed that the complex scheme as drawn by Ballegeer in Figure 7b, appears to have several inaccuracies for what concerns the representation of the façade, resulting in some inaccurate conclusions. For the present analysis, detailed survey plans are used to start over the whole process again from the beginning. The first thing we can observe reconsidering the town hall plans, is that the gable (attic) profile is based on an equilateral triangle that sits on the $3 \times 5 \times 7$ rods volume (Figure 15). This is a principle different from what we found for the other town halls (equilateral triangle vs. square division triangle).

Secondly, applying the quatrain scheme as proposed by Ballegeer, we see that the contouring square for the front façade accounts for the top of the stone pinnacles of the three turrets, but not for the roof ridge which is at a higher level. We should move the scheme $0.5 \operatorname{rod}=(7 \times 2) / 2=7$ feet up if we want to start reasoning from the roof ridge, as could be done for the other buildings.

Considering the two shifted schemes we notice now that:

- For the lower scheme, the equilateral triangle coincides with the metal node on the roof top of the mid turret and the roof planes of the two lower lucarnes;

74 Han Vandevyvere - Gothic Town Halls in and around Flanders, 1350-1550: a Geometrical Analysis 

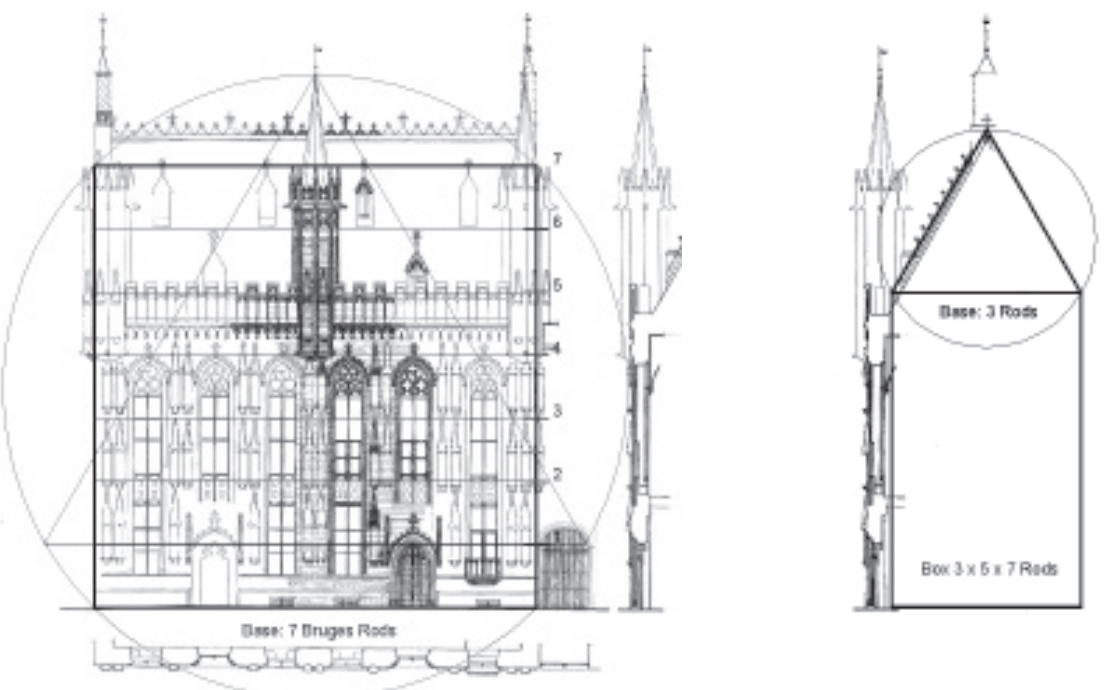

a)

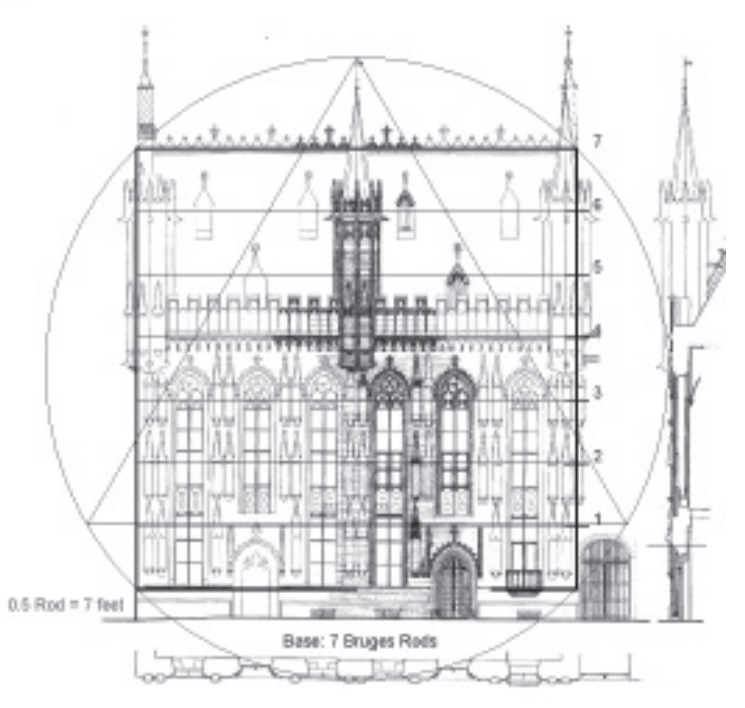

b)

c)

Figure 15. Town Hall at Bruges.

a) analysis of front façade;

b) analysis of building section;

c) analysis of front façade;

d) analysis of the plan.

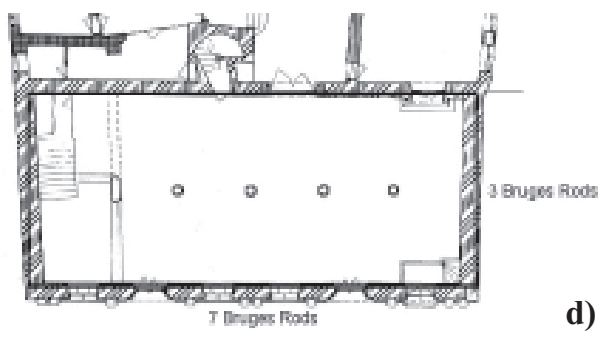


- The division in sevenths shows that the front door height corresponds with level $1 / 7$, the base of the turrets with level 4/7 and the balustrade top with level 5/7;

- For the upper scheme, the equilateral triangle coincides with the top of the metal flag of the mid turret;

- The base of the contouring square coincides with a ridge in the stonework and the baseline of the windows;

- The division in sevenths shows that level $1 / 7$ coincides with the top of the 6 front door pinnacles and level 4/7 gives the cornice line.

The link between the two 7 rod schemes is a 7 -foot displacement.

Summarizing the schemes for Bruges, we can say that:

- The building volume is elaborated following the local measurement system, and is basically defined by $3 \times$ ( 5 or 7$)$ x 7 Bruges rods;

- The front façade composition originates from two contouring squares of 7 rods;

- Drawing the quatrain scheme from these squares establishes some key points of the composition, and the same is in force to the division of the square in sevenths;

- The two quatrain schemes are shifted 7 Bruges feet one to each other.

After analysing these four buildings in a more or less extensive way, three other examples of Gothic town hall architecture of the low countries were examined, this time outside the actual Belgian territory. Depending on the amount of material that could be collected, the analysis is limited to a merely graphical inquiry of the front façade, or of the buildingplans. The results are a checkpoint for what has been put forward before.

\section{Veere, small cousin of Bruges}

The Gothic town hall of Veere, a small city situated in the province of Zeeland (the Netherlands) has been influenced by the Bruges design in a direct way (Figure 16). It was built between 1474 and 1517 , probably by Evert Spoorwater. The tower is from a later date, about the end of the sixteenth century, and is not further given consideration to here. The schemes shown in Figure 17 are self-explanatory.

Figure 16. The Gothic town hall of Veere, 1474 to 1517 .

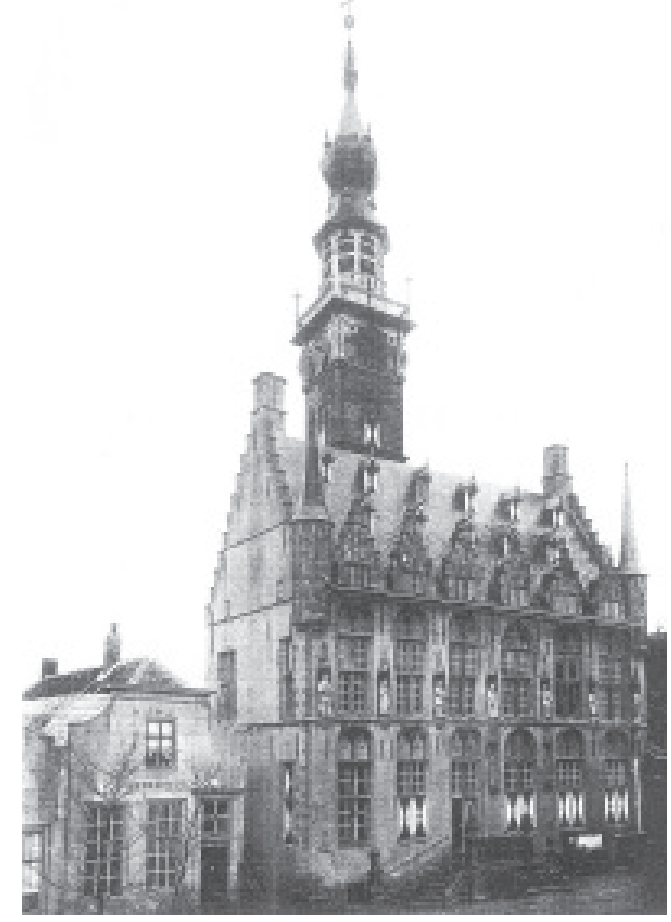

76 HAN VANDEVYVERE - Gotbic Town Halls in and around Flanders, 1350-1550: a Geometrical Analysis 
We summarize:

- The building is inscribed in a cubic grid, which is starting from the 0.00 floor level (note that in Bruges the 0.00 floor is exactly at street level). The central interior wall and the second floor are also located along the grid. In the front façade we find a countouring square as a result;

- The turrets have their base at half the height of this square, coinciding with the cubic grid;

- The attic profile is based on an equilateral triangle, as in Bruges, and has its top coinciding with the cubic grid;

- Drawing the division into sevenths, we notice that level 1/7 gives the door height, coinciding with a window division, level 4/7 gives the cornice and level 5/7 gives the top of the stonework of the turrets. The quatrain scheme itself does not provide more specific points.

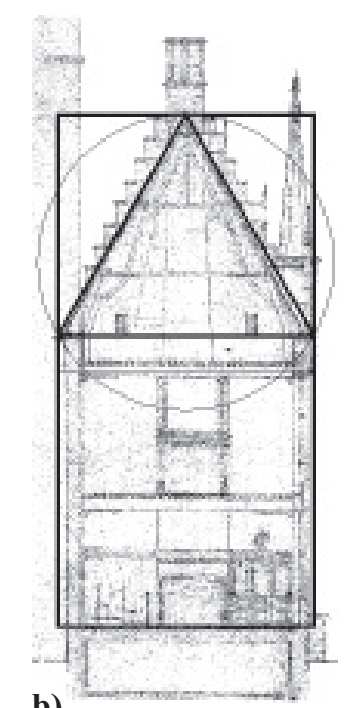

b)

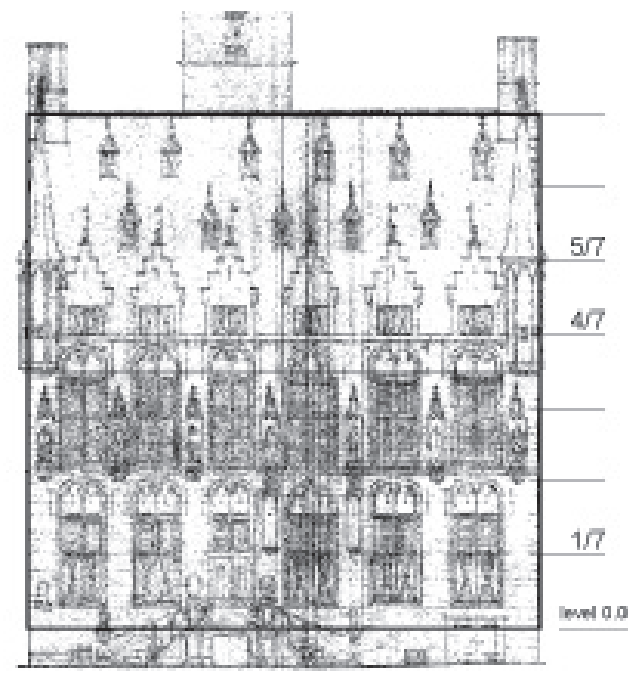

a)

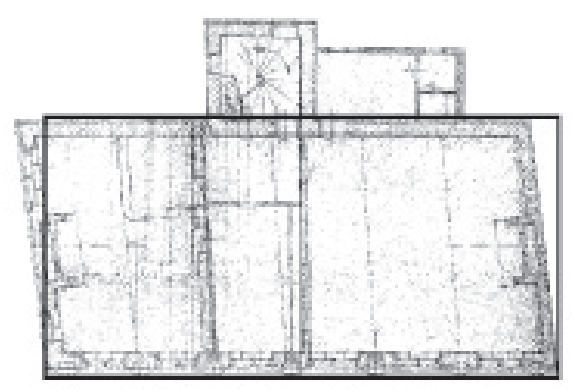

c)

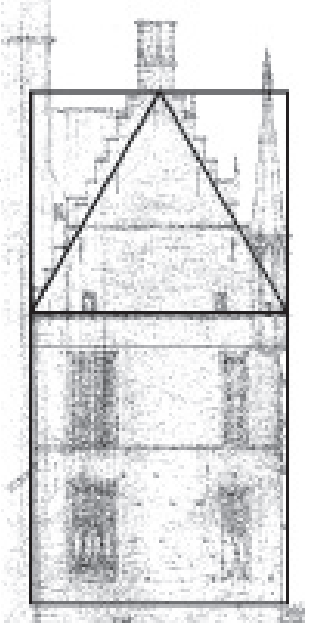

d)

Figure 17. Town Hall at Veere. a) analysis of front façade; b) analysis of building section; c) analysis of ground level plan; d) analysis of side facade. 


\section{Arras, the freestyler?}

The town hall of Arras was built from 1501 to 1506 . The adjacent belfry tower was started earlier, around 1460, and finished later, in 1554. The complex has been destroyed during the First World War and consequently been reconstructed, in 1922. At this occasion, the only element that is noticed to have changed in the front façade is the balcony (compare the photograph from 1914, Figure 18, with the reconstruction drawing, Figure 19). Such intentional changes appear to have aimed at restoring the medieval situation. Following the same philosophy, "anomalies" such as the eccentric position of the middle arch of the gallery have been meticulously respected. Most probably, all the redimensioning matches exactly the initial design. ${ }^{9}$

On the ground plan, Figure 18, we notice that the corpus behind the gallery has a footprint of three aligned squares. We will call the length of this figure $3 \mathrm{M}$, where $\mathrm{M}$ corresponds with the side of a composing square. The overall ground plan however, does not fit in a juxtaposition of squares or its derived rectangles. The front façade has then a contouring square of $3 \mathrm{M}$ if we consider its height up to the top of the gable finishings (they reach about 2 metres above the roof ridge). This is not as usually found for the other town

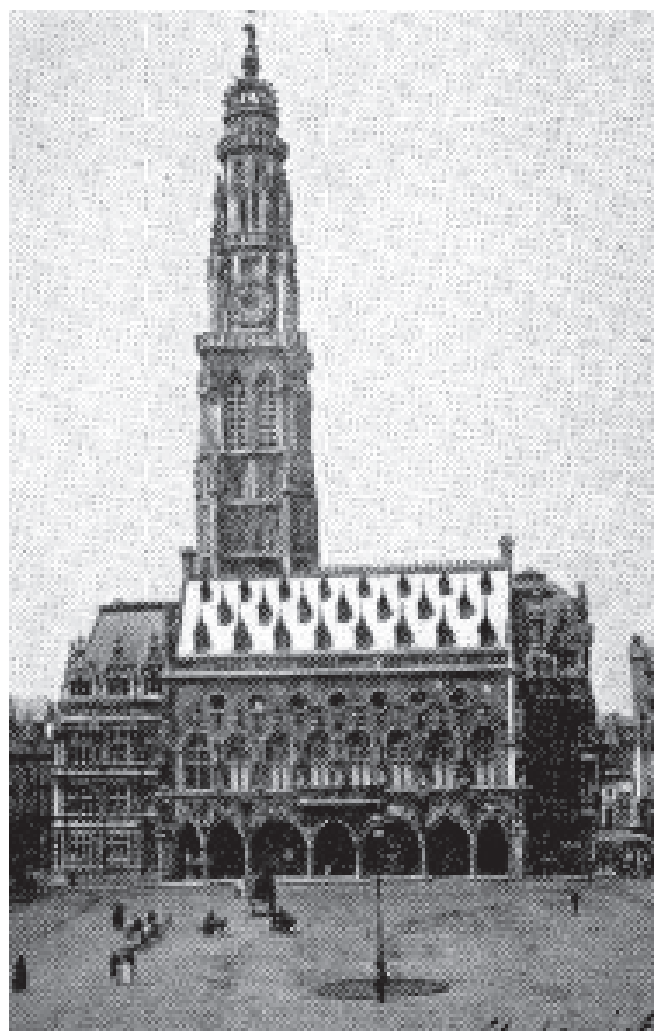

Figure 18. The Arras town hall before the destruction of 1914-1918. halls. However, if we analyse the design from the roof ridge downwards, we find the cornice on a distance $\mathrm{M}$ under this ridge and the main window ridge $2 \mathrm{M}$ under it, resulting in a partial series of six "groundplan squares" in the front façade, the series being displaced with respect to a regular nine square division. If we come back to the contouring square and draw the quatrain scheme on it, we see that the base of the equilateral triangle coincides with an outer buttress ridge, and that the lateral sides coincide with the tangents of the outer windows and oculi. This is a strong indication for the original intentionality of the contouring square as it is presented here. Strange however, is that a division in sevenths of this contouring square does not reveal anything. We should instead consider the height from the ground level up to the roof ridge. Dividing this distance in seven equal parts, we find the following: level $1 /$ 7 at the gusset of the arches, level 2/7 at the main window ridge, level $3 / 7$ at the secondary window ridge (not very visible on the scheme), level 4/7 through the centre points of the oculi, level 5/7 at the top of the balustrade and level 6/7 defining the 
height of the gable pinnacles. An additional interesting feature of the roof ridge is that the top of the belfry tower is exactly three times higher $(75 \mathrm{~m}$ against $25 \mathrm{~m}$ for the roof height). Summarizing, we can mention the following:

- A partial square grid can be discovered, but we cannot speak of a cubic grid;

- The contouring square can be drawn, but does not account for the roof ridge;

- Applying the quatrain scheme upon this square, we find some key lines for the composition;

- The division into sevenths doesn't work starting from the quatrain scheme, but starting from the roof ridge height.

Figure 19. Town hall of Arras.

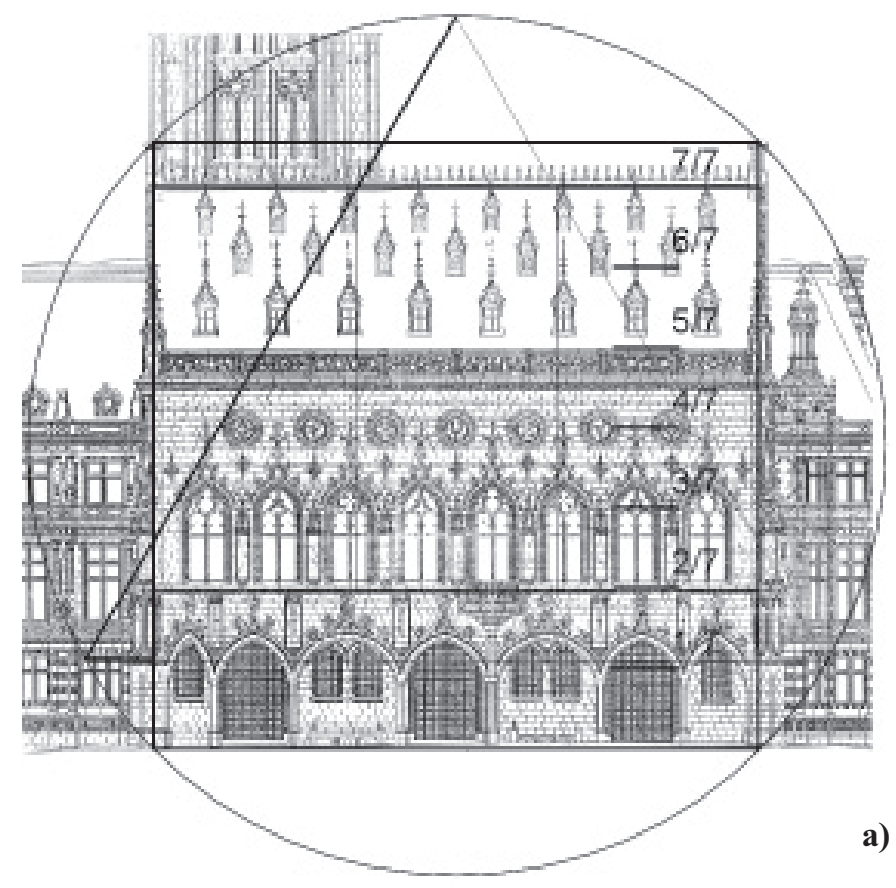

a) analysis of front façade;

b) analysis of plan.

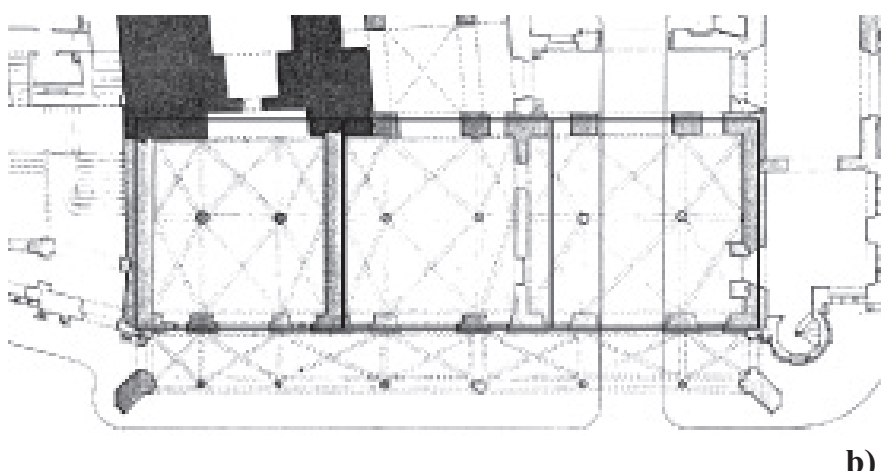

Nexus Network Journal - vol. 3, no 2, 2001 
If we assume that the reconstruction of the building after World War I was done carefully, we come to the conclusion that a very free and fragmentary interpretation of the design canons seems to have occurred in Arras.

\section{Saint-Quentin, a different concept fitting in with the classical rules}

The town hall of Saint-Quentin in Aisne (France) was finished in 1509. Colard Noël and Oudart de Marle can be put forward as possible designers of the building. It shows Renaissance influence (as Oudenaarde); the gallery has probably been copied from Arras.

For the analysis, we only have an old photograph to our disposal at this moment. It has been selected because of its very central, frontal camera-position, which guarantees a minimal lens deformation of the façade geometry. Given this, it was decided to risk the performance of an analysis directly on the photograph (Figure 20). Of course, a survey analysis would be desirable in the future. The tower was not considered since it is of a later and less interesting construction. We conclude:

- The front façade fits in a square. The design is probably based on a cubic grid, resulting in a subdivision of the contouring square in nine subsquares;

- Two quatrain schemes, one shifted R/2 to the other, can be drawn. The triangle of the shifted scheme coincides with the outer ridges of the three equilateral gables;

- The division into sevenths for the first scheme gives us the foot of the seven arches at level 1/7, the top of the arches at level 2/7 and the top of the (formal) balustrade at level 5/7.

Figure 20. Geometrical scheme for the main facade of Saint-Quentin.

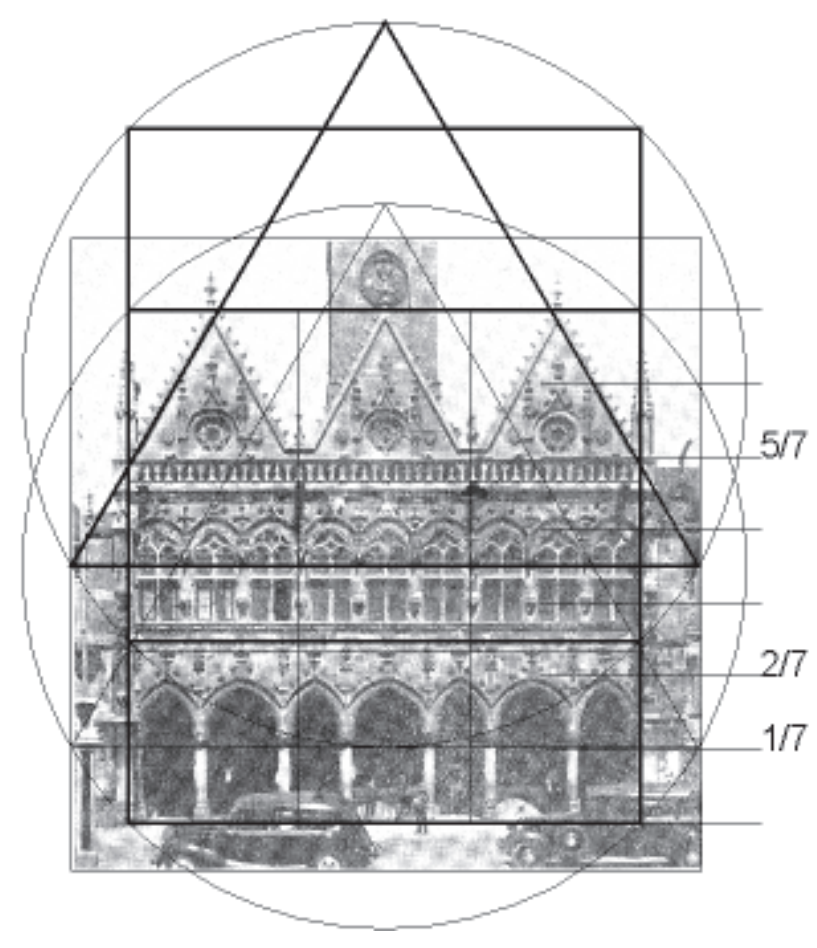

80 Han Vandevyvere - Gothic Town Halls in and around Flanders, 1350-1550: a Geometrical Analysis 


\section{Conclusions}

\section{The geometrical level}

From a mainly graphical analysis performed on seven cases, some hypotheses on the historical design schemes used for fourteenth to sixteenth century Gothic town halls in (or near) Flanders and Brabant can be formulated.

An initial set of probable design rules has been tested, leading to the conclusion that the following principles may very well have been in use when the master builders set out their projects:

1. The cubic grid: the main lines of the building respect a volumetry ordered by a juxtaposition of cubes. If not, we still find an expression of the main dimensions in simple series of local measurement units (the rod of the particular city where the building was constructed).

2. The front square: the front elevation, including the projection of the roof, is dictated by a contouring square. This square may be put on a socle.

3. The quatrain scheme: other key points of the main façade are ordered by this scheme, which represents a square, a circle and an equilateral triangle with the same centre point. Out of it derives a division of the square side in sevenths, which on its turn defines other elements of the composition.

These three principles reflect aspects of the basic organization of the building. The cubic grid can be considered as the "sketch design rule", but does not systematically refer to elements such as centre lines or exterior edges. In general, the precision of the schemes is at the highest in the front façades, and less pronounced in ground plans or building sections. Subdivisions of the façade or the positioning of interior walls and floors often show no direct concurrence with the schemes, and have for the present been analysed more systematically. However, in some cases such as Veere, there seems to be an obvious application of the principles for the interior subdivisions.

For other proportion rules, such as the use of the Golden Section, no evidence was yet found. Indeed, the Golden Section seems to be more important in Renaissance architecture.

It is obvious that fairly ideal examples are presented. There are interesting town halls out of the same period that present a more "chaotic" geometry, for example, because they were built in several phases and over a long period, or because the design was altered during the construction. More research should be carried on after this first exploration of the field. On the one hand, the geometrical investigation should go into more detail (surveys, in situ measurements). On the other hand, literature should be consulted further (inquiry of known design methods, in particular the teachings of the Compagnonnage).

\section{The symbolic level}

If a particular geometry was intended, it should be put against the framework of a certain time and space. Most probably, an interpretation of the geometry of the city hall designs within the paradigm of medieval symbolic thinking will be possible. Indications about this are currently being examined. 
Only a first reflection on the role of the city will be made here. The Flemish (and Brabant) cities obtained, through the thirteenth-fifteenth centuries, an advanced political independence. They became major trade centres for the known western world, and accumulated an inestimable amount of wealth. Bruges can, in a way, be considered as the New York of the fourteenth century. For example, the first stock exchange activities took place on a square in this town, giving origin to the term beurs (bourse, bolsa, borze, etc.). The cities were so powerful that they could threaten the king of France, impose their conditions on the Flemish counts, and so on. The mutual rivalry between the towns themselves resulted in numerous little wars - as far as they were not making coalitions against a common enemy. The city hall and the belfry tower were not only the most important institutional buildings of these communities, they were the very symbol of the civic pride and power and of a new consciousness.

Different elements indicate that, from a more metaphysic point of view, the city could be thought of as a microcosm. This microcosm forms part of the macrocosm, and obeys a parallel, similar set of rules. On the pragmatic level, for example, each town not only had its own jurisdiction and privileges, but also its own units of measurement. Apparently, this fact was more important than the chaos that must have resulted from endlessly recalculating quantities or adapting rules while going from one city to another. Consequently, the emblematic city hall was always set out in local measures - and this was only the beginning of a more complex symbolic story. The front façade, which is the "face" of the town hall and of the city, can in its turn be regarded as a symbolic representation of this microcosm. The square and the circle add up to a mandala, ${ }^{10}$ an archetypical form representing the relation between the earth (the square, the finite) and the universe (the circle, the infinite). The façade of the town halls in our analysis is a square, and thus the absolute expression of earthly strength and stability. But in its relation to the circle, it refers as well to the metaphysical. This combination of both elements is very essential, for in the middle ages, one never put forward anything without considering its proper place in the cosmic order.

\section{Notes:}

1. Citation from "Die Satzungen des Regensburger Steinmetzentages nach dem Tiroler Huttenbuche von 1460", in Zeitschrift fur Bauwesen 46 (1896), quoted in [Shelby 1977: 168].

2. With regard to these measurement systems, it has been proved that they stayed in use nearly unchanged until the French Revolution. At the moment of the introduction of the metric system, commissions were set up by the French in every new "Département", to establish very precisely the relations between the old and the new measurement units. The reports of these commissions compose a capital source of knowledge about the medieval measurement systems. A detailed description is to be found in [Vandewalle 1984].

3. "A point in a circle / And that can be situated in the square and the triangle / Do you know the point? All is for the better / Don't you know it? All is in vain."

4. This point of view will be put in perspective below when considering the town hall as a microcosm within the macrocosm, the first obeying to and representing the same principles as the latter.

5. See Appendix: "origin of survey plans and models used" below for more details on sources.

82 Han Vandevyvere - Gothic Town Halls in and around Flanders, 1350-1550: a Geometrical Analysis 
6. One should always be suspicious about the originality of these balustrades, because they were sometimes added, mostly in the nineteenth century, to obtain a more "high" Gothic look. An example is the St.-Pieter's church in front of the Louvain town hall. Another example, where this happened with the town hall is Middelburg (the Netherlands).

7. For an additional hypothesis on the construction of the first building plan, [Vandevyvere 2000: 185-188].

8. For an introduction on the Compagnons, see [Bayard 1977]. The organization still exists today and forms highly skilled craftsmen who are trained in particular for restoration work.

9. This can however not be said with absolute certainty. In the future, some archive files residing in Paris could bring more clarity about the details of the reconstruction process. We do know for example, that the arches of the front façade were recuperated for the reconstruction.

10. C.G. Jung points out that the Mandala scheme can often be found in medieval representations. See [Jung 1993] and [Jung 1963].

\section{Acknowledgments}

I would like to thank architects and collaborators of archives and technical services for providing me with building-plans and data. Mr. Van Rompaey for the Louvain survey, Mrs. Van De Cappelle for reviewing the text from linguistic point of view, and Prof. H. Neuckermans for giving me time, tools and confidence.

\section{Appendix: origin of survey plans and models used}

\section{Louvain}

Survey plans from the "Technische Dienst Stad Leuven" (Louvain technical services) and in situ control measurements of major points of the building served for the construction of the presented computer drawings.

Survey plans of the "Technische Dienst" were presumably made in 1953 by architect A. Moerkerke.

Topographical control measurements were done by Anton Van Rompaey and Han Vandevyvere in 1999.

\section{Oudenaarde}

Survey plans obtained from the "Technische Dienst Stad Oudenaarde". Mixed set of plans made around 1938, 1966 and 1993.

Brussels

Survey plans from the "Technische Dienst Stad Brussels".

Bruges

Survey plans made by architects J. and L. Vierin in 1939, except ground plan after L. Devliegher.

Veere

Survey plans obtained through the "Zeeuws Archief" (archives of the Dutch Province of Zeeland, Middelburg), coming from the "Centrale Dienst Gemeentewerken", Serooskerke, Zeeland. 
Arras

Reconstruction plans obtained from the "Archives départementales du Pas-de-Calais", plans made in 1924 by architect P. Paquet.

Saint-Quentin

Photograph reproduced from M. Battard and J. Lestocquoy, Beffrois, halles, hôtels de ville dans le Nord de la France et la Belgique, Commission départementale des monuments historiques du Pas-de-Calais. Etudes historiques 2 (Arras: Brunet, 1948).

NB: All plans are twentieth century surveys, made for documentation, maintenance and restoration purposes.

\section{References}

Ballegeer, J. 1987. Stadhuis Brugge, De Gulden Engel. Wommelgem.

Bayard, J.-P. 1977. Le Compagnonnage en France. Paris: Payot.

Ghyka, M. 1969. Le nombre d'or: rites et rythmes pythagoriciens dans le développement de la civilisation occidentale. Paris: Gallimard.

Jung, C.G. 1963. Herinneringen, dromen, gedachten. Arnheim: Van Loghum Slaterus. 1993. Symboliek van de Mandala. Rotterdam: Lemniscaat.

Maesschalck, A. and J. Viaene. 1960. Het stadhuis van Brussel (Mensen en bouwkunst in Boergondisch Brabant). Louvain.

Shelby, L.R. 1977. Gothic design techniques: The fifteenth-century design booklets of Mathes Roriczer and Hanns Schuttermayer. Carbondale and Edwardsville (IL): Southern Illinois University Press.

Vandevyvere, Han. 2000. Het stadhuis van Leuven: een geometrische analyse. Jaarboek van de geschied- en oudheidkundige kring voor Leuven en omgeving 39: 171-192.

Vandewalle, P. 1984. Oude maten, gewichten en muntstelsels in Vlaanderen, Brabant en Limburg (Belgisch centrum voor landelijke geschiedenis 82). Ghent.

\section{About the author}

Engineer-architect Han Vandevyvere graduated from Katholieke Universiteit Leuven in 1989. Since then he has combined working at the Computer Aided Architectural Design research group of the Architecture Department, Katholieke Universiteit, Louvain under Prof. H. Neuckermans, with practicing as an architect. He is presently at Modulo Architects, Brussels. Work at CAAD research group has included digital reconstruction of the building history of the Louvain town hall. Work in construction practice has included historic-archaeological research on Gothic houses, for restauration purposes. More about Han Vandevyvere can be learned from his homepage, http:// www2.asro.kuleuven.ac.be/asro/english/HOME/Hvdv/han.htm 